\title{
8.5 Predictors of long-term outcome of Juvenile Dermatomyositis (JDM): a Multicenter, Multinational Study of 490 patients
} C Ferrari*1, L Trail11, C Pilkington², S Maillard ${ }^{2}$, R Cuttica ${ }^{3}$, MM Katsicas 4 , R Russo $^{4}$, M Bandeira ${ }^{5}$, V Ferriani ${ }^{6}$, S Oliveira ${ }^{7}$, C Saad-Magalhaes ${ }^{8}$, CA Silva9 , V Baca ${ }^{10}$, R Burgos-Vargas ${ }^{11}$, E Solis-Vallejo ${ }^{12}$, M Alessio $^{1}$, MG Alpigiani ${ }^{1}$, F Corona ${ }^{1}$, F Falcini ${ }^{1}$, V Gerloni ${ }^{1}$, L Lepore ${ }^{1}$, S Magni-Manzoni ${ }^{1}$, F Zulian ${ }^{1}$, N Ruperto ${ }^{1}$, A Pistorio1 ${ }^{1}$, E Felici ${ }^{1}$, F Rossi ${ }^{1}$, E Sala ${ }^{1}$, A Martini ${ }^{1}$ and A Ravelli ${ }^{1}$

Address: ${ }^{1}$ Italian Pediatric Rheumatology Study Group, Italy, Italy, ${ }^{2}$ Great Hormond Street Hospital, London, UK, ${ }^{3}$ Hospital General de Ninos Pedro de Elizalde, Buenos Aires, Argentina, ${ }^{4}$ Hospital Garrahan, Buenos Aires, Argentina, ${ }^{5}$ Hospital Pequeno Principe, Curitiba, Brazil, ${ }^{6} \mathrm{Hospital}$ da Universidade, Riberao Preto, Brazil, ${ }^{7}$ Universidade Federal do Rio de Janeiro, Rio da Janeiro, Brazil, ${ }^{8}$ Hospital das Clínicas UNESP, Botucatu, Brazil, ${ }^{9}$ Hospital das Clínicas, Sao Paulo, Brazil, ${ }^{10} \mathrm{CMN}$ Siglo XXI, Mexico City, Mexico, ${ }^{11}$ Hospital General de México, Mexico City, Mexico and ${ }^{12}$ CMN La Raza, Mexico City, Mexico

* Corresponding author

from I5th Paediatric Rheumatology European Society (PreS) Congress

London, UK. 14-17 September 2008

Published: 15 September 2008

Pediatric Rheumatology 2008, 6(Suppl I):SI9 doi:I0.II86/I546-0096-6-SI-SI9

This abstract is available from: http://www.ped-rheum.com/content/6/SI/SI9

(C) 2008 Ferrari et al; licensee BioMed Central Ltd.

\section{Background and objective}

Little information exists on long-term outcome of JDM. Furthermore, most studies have been conducted in single centres or have involved a few patients. Objective of the study is to identify predictors of a poorer long-term outcome of JDM in a multicenter cohort of patients.

\section{Methods}

490 patients with JDM and disease duration $>2$ years seen in 27 centers in 5 countries (Italy, UK, Argentina, Brazil, Mexico) after 1980 were identified. Outcomes included muscle weakness (MMT), continued activity (DAS), cumulative damage (MDI), calcinosis, lipodystrophy, functional impairment (CHAQ), and health-related quality of life (HRQL) impairment (CHQ). Predictors included: continent (Europe vs. Latin America), gender, year of onset, onset age, onset type (acute vs. insidious), onset manifestations, severity of muscle/skin manifestations at onset, and course type (monocyclic, polycyclic, chronic continuous).

\section{Results}

Table 1 shows significant predictors for each outcome.

Table I:

\begin{tabular}{llllll}
\hline (*At onset) & M. weak'ss & Cont'd activity & Damage & Funct. Impairm'nt & HRQL Impairm'nt \\
\hline Female sex & + & - & - & + & - \\
Onset after 2000 & + & - & - & - & - \\
Onset age $<5$ yrs & - & - & - & - & - \\
Onset type & - & - & - & - & - \\
Dysphonia* & + & - & - & - & + \\
Mm/skin severity* & - & + & + & + & + \\
Chronic Course & + & & & &
\end{tabular}




\section{Conclusion}

The chronic continuous course predicted all outcomes, which highlights the critical need for treatments and treatment strategies that have the ability to better control disease activity over time.

Publish with Biomed Central and every scientist can read your work free of charge

"BioMed Central will be the most significant development for disseminating the results of biomedical research in our lifetime. " Sir Paul Nurse, Cancer Research UK

Your research papers will be:

- available free of charge to the entire biomedical community

- peer reviewed and published immediately upon acceptance

- cited in PubMed and archived on PubMed Central

- yours - you keep the copyright

Submit your manuscript here:

http://www.biomedcentral.com/info/publishing_adv.asp 